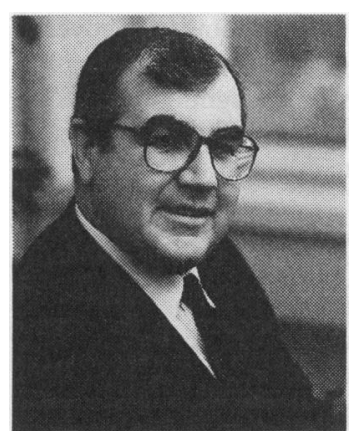

Alan Langlands, chief executive of the NHS offered inducements such as enhancements to salary and particularly generous removal expenses to take a post with a trust." Managers are allegedly offering such inducements subject to confidentiality being maintained.

\section{Parliamentary questions}

(27) The parliamentary unit at the BMA commented on the striking number of parliamentary questions that receive the answer "The information requested is not held centrally."

(28) In February 1993 Hansard reported that Ian McCartney, then opposition spokesman for health, asked the secretary of state for health what advice she had received from the independent assessors nominated by the Royal College of Pathologists on awarding the private contract for pathology services for the North Hertfordshire trust and what action was taken as a result of that advice. Tom Sackville, the under secretary of state for health, replied that "the advice of the assessors nominated by the Royal College of Pathologists was given in confidence to the North Hertfordshire trust. We understand that the trust has found the advice valuable in its discussions on the detail of the service to be provided under contract."

(29) In November 1994 Hansard reported that Jim Cousins, Labour spokesman on foreign affairs, asked the secretary of state for health "if she will place the Touche Ross report on the Prescription Pricing Authority in the Library." Gerry Malone replied "No. As part of the market testing process, a number of reports have been prepared for the Prescription Pricing Authority by Touche Ross and others. Those reports contain information which is commercially sensitive."

(30) In February 1994 Hansard reported that Gerry Steinberg (Labour, City of Durham) asked the secretary of state for health "if she will list by region the hospitals that have closed since 1990 and also those that have opened in the same time period." Tom Sackville replied that "Decisions on opening or closing facilities are for local management. The Department requires formal notification only where proposed closures are contested by the community health councils."

\section{Smith R. Twenty steps towards a "closed society" on health. BMf 1987;295: 1633-4. \\ Frankel M. Medical secrets. New Scientist 1994;Dec 3.51.}

3 Sheard S. Gagging public health doctors. BMF 1994;309:1643-4.

\section{Gagging public health doctors}

\author{
Sally Sheard
}

On 1 April 1996 the last vestiges of public health advocacy in Britain will be abolished when the eight regional health authorities are replaced by eight analogous NHS Executive regional offices.' The regional directors of public health and their staff will become civil servants and hence constrained in speaking out on matters of public health. One consequence will be that the directors, the leaders of public health medicine, will not be allowed to become office holders in the Faculty of Public Health Medicine.

From its inception, public health has held a unique place in the British medical establishment. Public health doctors must often speak out against governmental and public opinion in the interest of the public health. As our expectations for quality of life and health care have increased, so has the scope for intervention in all aspects of public and private life. Thus advocacy and the right of free speech have long been intrinsic components of the public health movement, and they have been regularly attacked.

\section{Conflicts of the first medical officer of health}

In 1847, after the appointment of William Henry Duncan in Liverpool as the country's first medical officer of health, Punch satirised the part time position which left Duncan at the mercy of his private patients. If the Officer of Health recommended by $\mathrm{Mr}$ Punch shall have for a patient a rich butcher, with a slaughter house in a populous neighbourhood, an opulent fellmonger or tallow chandler, with a yard or manufactory in heart of town, he shal not hesitate from motives of interest to denounce their respective establishments as nuisances, he shall not fail to point out the insalubrity of any gas-works, similarly situated, the family of whose proprietor he may attend; and if any old lady who may be in the habit of consulting him shall infringe the Drainage Act, he shall not fail to declare the circumstances to the authorities. ${ }^{2}$

Punch provided an amusing if crude description of the relationships which Duncan was forced to endure through his contract with Liverpool Town Council.
Thankfully, the council recognised the importance of the independent status for the officers of health, and Duncan was given a full time position later that year.

More recently, the royal colleges and the public health profession supported Keith Barron's Private Member's Bill for the Abolition of Tobacco Advertising. In response the Department of Health said that government policy superseded the established public health doctrine that smoking is harmful to health and that public health practitioners were in no position to advise members of parliament to support the bill. If this is the response of the Department of Health to public health practitioners who are still functionally independent from central government, what will happen in 1996?

\section{Closing the door on free speech}

Sadly, much of the freedom of public health professionals has already been surrendered. In 1988 the report of the Committee of Inquiry into the Future Development of the Public Health Function, which was chaired by the then chief medical officer, Sir Donald Acheson, concluded: "We therefore reject the view expressed in some of the evidence submitted to us that public health doctors, employed in the public sector, have a duty or a right to advocate or pursue policies which they judge to be in the public interest independently of any line of accountability. In the extreme this would place them in a position above Parliament."3

The Acheson report suggested that the advisory function would be most effectively carried out through representation to the local health authority, and in the same year the response from the president of the Faculty of Community Medicine concurred with this. ${ }^{4}$ Even by this date, however, the local health authorities had lost much of their independent status. The battle had effectively been lost in 1974, when centrally appointed health authorities inherited the responsi- 
bility for preventive medicine from locally elected regional councils.

\section{Still time for a reprieve}

Given this background to the public health advocacy debate, why will the changes of 1 April 1996 be so significant? As the public health practitioners become civil servants they will have to make a cultural shift and recognise that their primary role is to serve not the public but ministers. Views that do not fit with governmental policy are unlikely to be tolerated.

Thus public health as a profession and an ideology is in danger of being overwhelmed by the machinery of central government. This parallels the situation faced by Sir John Simon in 1859. He recognised the potential for change from within and began his career in state medicine in an optimistic mood. Entrance into the civil service worked in favour of the medical profession at this time: it boosted their professional status and redressed the "sanitary engineering" bias of an earlier era. But Simon soon realised the inflexibility of government policy, and his effective exclusion from shaping public health legislation forced his resignation in 1876 . His aspirations for incorporating the benefits of local government into the state medicine system had been thwarted.

The legislation for the abolition of the regional health authorities has not yet been introduced to parliament, and possibly this gives some cause for optimism. This will provide a final opportunity to present the case for an independent public health system which respects the rights of advocacy and free speech. It is only in such a system that the essential tasks can be undertaken honestly and effectively.

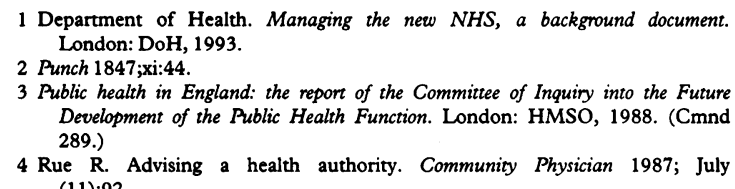
(11):92.

\section{An unfree NHS and medical press in an unfree society}

\section{Richard Smith}

Last year I wrote an editorial on free speech but was stopped from publishing it. Our lawyers and insurers advised against publication. The full story still cannot be told. I will say, however, that the editorial was written in a white heat after receiving faxes from two sets of lawyers saying that if we published anything on a particular topic without consulting them legal action would follow. I had never heard about the topic until we received the faxes, and my instincts were to find out everything I could and publish a full story. Unfortunately that could not be, but much of the editorial I wrote concerned the general issue of free speech within the NHS and in medical journals. A revised version of that editorial is printed below.

Free speech has probably never existed within the NHS, and seven years ago we gathered together 20 examples of where attempts had been made to suppress important health information. ${ }^{\prime}$ Today we publish a second set of examples (p 1640), ${ }^{2}$ and most NHS employees feel that restrictions on freedom of speech have become much more severe since the health service has become more commercial. ${ }^{34}$ Speaking up on
BMU, London WC1H 9JR Richard Smith, editor deficiencies within a hospital was once a public duty; now it is viewed as a betrayal of the competitive interest of the NHS trust. Gagging clauses have been written into the contracts of NHS consultants and other employees, and there have been several high profile cases of whistleblowers being persecuted. ${ }^{6-8}$ Public anxiety that matters of great public importance were being suppressed compelled the government to produce a "whistleblowers' charter," but many observers thought that the charter made life easier for those who wanted to suppress information rather than for those who wanted to blow whistles. ${ }^{10}$

Effective organisations encourage internal debate and dissent, ${ }^{11}$ and the NHS Executive wants NHS employees to talk to their managers about problems in the service. ${ }^{8}$ Unfortunately, employees are sceptical about this message of glasnost from the top because of aggressive local managements, ${ }^{12}$ instructions not to talk to anybody outside the service without consulting management, gagging clauses written into contracts, and clear examples of persecution of those who take their worries to the stage of talking to the press.

\section{Britain: a society with an unfree press}

Yet we in Britain should not be surprised that NHS managers attempt to restrict free speech-because we live in a society that sets a low value on free speech. NHS managers are learning from their superiors. The United States has freedom of speech written into its constitution and a Freedom of Information Act, whereas Britain has no written commitment to free speech and a vast array of restrictive laws and practices that culminate in an Official Secrets Act. We at the $B M F$ see this most clearly in terms of freedom of the press. Britain, argues the Columbia foumalism Review, the world's leading scholarly publication on journalism, has an unfree press that is facing a crisis. "What has happened," the review asks, "to the land of Magna Carta?"

A free press lies at the heart of a free society. When the United States Supreme Court allowed the publication of the Pentagon papers by the American press, it said:

In the First Amendment the Founding Fathers gave the free 